\title{
Impact of dietary glutamine on amino acid digestibility values and intestinal morphometric parameters in neonate chicks
}

\author{
N.F. Namroud ${ }^{1 \#}$, M. Shivazad ${ }^{1 \#, ~ M . ~ Z a g h a r i ~}{ }^{1}$, O. Madadgar ${ }^{2} \&$ K. Nourijelyani ${ }^{3}$ \\ ${ }^{1}$ College of Agriculture and Natural Resources, University of Tehran, Animal Science, Iran \\ ${ }^{2}$ Faculty of Veterinary Medicine, University of Tehran, Microbiology and Immunology, Iran \\ ${ }^{3}$ Tehran University of Medical Science, Epidemiology and Biostatistics, Iran
}

(Received 25 October 2015; Accepted 15 January 2016; First published online 22 May 2017)

\author{
Copyright resides with the authors in terms of the Creative Commons Attribution 4.0 South African Licence. \\ See: http://creativecommons.org/licenses/by/4.0/za \\ Condition of use: The user may copy, distribute, transmit and adapt the work, but must recognise the authors and the South African \\ Journal of Animal Science.
}

\begin{abstract}
Two experiments were conducted to investigate the effects of fortification of the pre-starter diet with glutamine in post-hatch broiler chicks. In the first experiment, male chicks were used to study the impact of glutamine supplementation at three levels $(0 \%, 1 \%$ and $2 \%)$ on performance, apparent faecal digestibility (AFD) and ileal digestibility (AID) of amino acids (AAs), as well as intestinal morphometric parameters from 0 to 14 days old. The best performance was obtained at $1 \%$ supplementation. Average daily feed intake and feed conversion ratio (FCR) were affected by treatments. Supplementing diets with glutamine resulted in increase of digestibility values for arginine (Arg), lysine (Lys), isoleucine (lle) and valine (Val). Glutaminesupplemented diets led to higher villus height (VH) and shallower crypt depth (CD) in the jejunum and ileum. A second experiment was performed to investigate whether the form of glutamine could affect performance and morphometric parameters in newly hatched chickens. A control diet was prepared, based on casein as the sole source of protein-bound AAs. Three diets based on synthetic AAs were used to obtain nutrient values of the control diet, which were supplemented with a synthetic form of glutamine, glutamic acid and a $50: 50$ ratio of glutamine : glutamic acid. Chickens fed the control diet presented higher average daily weight gain and better FCR. None of the AID coefficients of amino acids were influenced by the dietary treatments, except glutamic acid and aspartic acid, which were decreased in chicks fed synthetic AAs. In conclusion, $1 \%$ glutamine supplementation improved performance, morphometric parameters and AID and AFD values of cationic AAs. The form in which dietary glutamine was provided could affect performance.
\end{abstract}

Keywords: Amino acid, broiler, digestibility, intestinal morphology

\#Corresponding author: shivazad@ut.ac.ir, nebonidnamroud@hotmail.com

\section{Introduction}

The post-hatch developmental period represents a critical phase in attaining quality broiler performance at marketing. The importance of dietary protein and amino acid (AA) quality and quantity as significant compounds of diet during this phase of a chicken's life has been documented (Noy \& Skalan, 2002; Noy \& Uni, 2010; Gous, 2010; Panda et al., 2013). Neonatal broiler chicks are more susceptible to low levels of protein in the diet than to the lack of other macronutrients (Swennen et al., 2010; Hada et al., 2013). Consumption of a high-protein diet, regardless of the differences in bioavailability coefficients of AAs in various sources of protein, is the usual strategy in feed formulation for neonatal chickens. This often ensures optimum growth during and after the critical period of birds' life. However, providing protein above the animal's requirements may not always guarantee performances in neonatal animals.

In high crude protein (CP) diets, the concentration of non-essential AAs increased that may play an effective role after birth. Glutamine (GIn), as one of the non-essential AAs could serve as an oxidative fuel for enterocytes and immune cells, a precursor of purine and pyrimidine synthesis, a modulator of protein turnover or an intermediary for gluconeogenesis, acid-base balance and redox homeostasis. Therefore, Gln is an irreplaceable precursor for certain biologically vital molecules (Souba, 1993). Because of two active nitrogen groups and carbon skeleton, Gln as a nitrogen and carbon transmitter causes rapid turnover of plasma Gln pool (Curthoys et al., 1995). Glutamine tracer kinetic studies in human beings have shown that up to $30 \%$ of the Gln pool is used for macromolecule synthesis (Biolo et al., 2005). The Gln molecule is responsible for maintaining the intestinal mucosa structure which is acting as a barrier against bacteria (Khan et al., 1999), in addition to boosting the maturity and integrity of the intestinal flora associated with the 
immune system (Yi et al., 2005; Murakami et al., 2007), a Gln supply might improve intestinal conditions for better nutrient absorption. The positive effects of $\mathrm{Gln}$ on the performance of broilers in various situations have been documented (Dai et al., 2009; 2011; 2012; Nassiri Moghadam \& Alizadeh-Ghamsari, 2013). Nevertheless, little research has been conducted on the effects of Gln supplementation of broiler pre-starter diets on other AA absorption during and post-hatch. In addition, the modality of Gln supplementation as a synthetic free AA or as part of an intact polypeptide or protein molecule and its consequent responses have been less studied.

Because of the obvious effect of GIn on the histo-morphological condition of the epithelial cells of the mucosa, the first experiment was carried out to evaluate the effects of graded levels of dietary Gln on performance, apparent faecal digestibility (AFD) and ileal digestibility (AID) values, and morphology of the intestinal mucosa in newly hatched chicks. The second experiment was conducted to compare the effects of an intact protein-bound source of Gln, casein, and a synthetic source of L-Gln on performance, AID values, and morphological parameters of the intestinal mucosa.

\section{Materials and Methods}

Experiment 1 was performed to examine whether the inclusion of dietary Gln might affect histomorphometric parameters of the intestine and essential AA digestibility in newly hatched chicks. A total of $240\left(3^{\star} 5^{\star} 16\right)$ newly hatched broiler chicks was randomly allotted to 15 four-floor electrically heated battery cages on arrival at the research facility. To minimize the weight range of newly hatched chicks, 3000 eggs of uniform weight $(60 \pm 1.5 \mathrm{~g})$ were selected from 6500 eggs. Twenty trays of 150 eggs were labelled and followed throughout the incubation period. For the first 18 days of incubation, the temperature was set at $37.8 \stackrel{\circ}{\circ}$, with $52 \%$ relative humidity. Eggs were turned every hour. From day 18 until hatch, the temperature and relative humidity were reduced to $36.5^{\circ} \mathrm{C}$ and $48 \%$, respectively. On day 18 of incubation, the eggs were candled. Those with evidence of live embryos were transferred to the hatcher. At the end of incubation period, hatched chickens were sexed and weighed. Therefore, 240 day-old healthy male Ross 308 chicks with relatively similar bodyweights $(38 \pm 0.3 \mathrm{~g}$ ) were selected and wing-tagged to be allotted to one of the three dietary treatments. Housing conditions were controlled throughout the experimental period, and chicks had ad libitum access to feed and water. The treatment diets were formulated to meet the National Research Council (NRC 1994) minimum recommendations, and were fed from 0 to 28 days old. Soybean meal, as the sole source of intact protein, was sampled before the diet was formulated to determine CP as Kjeldahl nitrogen $\times 6.25$, moisture, ether extract, ash, crude fibre and total AA content (Evonik-Degussa GmbH). The amounts of calcium (method 927.02), phosphorus (method 965.17), potassium (method 969.23), sodium (method 969.23) and chloride (method 943.01) were analysed in duplicate samples by AOAC (2015) procedures in all unpurified feeding ingredients. Diets were formulated to provide constant amount of the mentioned elements in all treatments. All of these elements were maintained constant in all treatments. The experimental diets were formulated to be isoenergetic (Table 1) with cellulose as filler (Table 2). Diets were presented as crumble, and supplemented with complete vitamin and trace mineral mixes.

Experiment 2 was carried out to determine the differences between providing Gln and Glu in the form of casein (protein-bound AA) and as a crystalline form of AA (99.6\% purity). Casein was sampled before the diets were formulated to determine nutrient content, including all essential AAs, as described previously. All diets were formulated to be iso-energetic $(12.67 \mathrm{MJ} / \mathrm{kg}$ of apparent metabolizable energy). The levels of calcium, phosphorus, sodium, potassium and chlorine were maintained equally in all treatments (Tables 3 and 4). Four purified dietary treatments - consisting of various sources of Gln and Glu, including casein, a crystalline form of Gln, a crystalline form of Glu, and 50:50 blend of Glu : Gln - were prepared to provide equal total amounts of Gln and Glu (Table 3). For maintaining the total amount of essential AAs equal and above the NRC (1994) recommended levels in all treatments (Table 4), crystalline AAs were added to equal the levels of those in the diet that included casein. Feed grades of L-Lys HCl, DL-Met and L-Thr were used in the diets, whereas for other AAs, reagent grade (minimum 99.5\% purity) was provided.

On days $0,4,7$ and 14 post hatch, five chicks per treatment (with bodyweight close to average) were weighed, stunned electrically, euthanized and the abdominal cavities opened. The small intestine was removed and divided into three segments: duodenum, from the pylorus to entry of the bile and pancreatic ducts; jejunum, from the distal portion of the duodenal loop to Meckel's diverticulum; and ileum, anterior portion of the ileocecal junction.

Segments were cut longitudinally and flushed with cold phosphate-buffered saline (PBS). For morphometric measurement, approximately $3 \mathrm{~cm}$ of the middle portions of the duodenum, jejunum and lleum (the apex of the duodenum, $2 \mathrm{~cm}$ proximal to Meckel's diverticulum, 8 to $10 \mathrm{~cm}$ proximal to ileocecal junction) were cut with a razor blade and fixed in $10 \%$ buffered formalin solution for 10 days. Five crosssections of $70 \%$ 
Table 1 Nutritional values of the experimental diets (Experiment 1)

\begin{tabular}{lccc}
\hline \multirow{2}{*}{ Ingredient } & \multicolumn{3}{c}{ Experimental diets } \\
\cline { 2 - 4 } & $\mathbf{0 \%}$ Glutamine & $\mathbf{1 \%}$ Glutamine & $\mathbf{2 \%}$ Glutamine \\
\hline Calculated composition & & & \\
$\quad$ Apparent metabolizable energy $(\mathrm{MJ} / \mathrm{kg})$ & & 12.67 \\
$\quad$ Available phosphorus $(\mathrm{g} / \mathrm{kg})$ & 5.3 & \\
Sodium $(\mathrm{g} / \mathrm{kg})$ & & 2.0 & \\
Chlorine $(\mathrm{g} / \mathrm{kg})$ & & 1.9 & \\
Potassium $(\mathrm{g} / \mathrm{kg})$ & & 8.6 & \\
Analysed composition & & & \\
Crude protein $(\mathrm{g} / \mathrm{kg})$ & 233.6 & 233.6 & 233.6 \\
Calcium $(\mathrm{g} / \mathrm{kg})$ & 10.9 & 10.9 & 10.9 \\
Lysine $(\mathrm{g} / \mathrm{kg})$ & 14.4 & 14.4 & 14.4 \\
Methionine $+\mathrm{cystine}(\mathrm{g} / \mathrm{kg})$ & 10.9 & 10.9 & 10.9 \\
Threonine $(\mathrm{g} / \mathrm{kg})$ & 10.3 & 10.3 & 10.3 \\
Tryptophan $(\mathrm{g} / \mathrm{kg})$ & 12.6 & 12.6 & 12.6 \\
Arginine $(\mathrm{g} / \mathrm{kg})$ & 15.4 & 15.4 & 15.4 \\
Valine $(\mathrm{g} / \mathrm{kg})$ & 11.1 & 11.1 & 11.1 \\
Isoleucine $(\mathrm{g} / \mathrm{kg})$ & 9.7 & 9.7 & 9.7 \\
\hline
\end{tabular}

ethanol preserved segments for each sample were prepared and embedded in low-melt paraffin (Beçak \& Paulete, 1976). Sections were cut from the waxed tissue on a Leitz 1512 microtome. Samples were then stained with haematoxylin and eosin (Uni et al., 1995). Six of the straightest most intact villi and associated crypts were selected for each intestinal cross-section. VH is defined as the length from the villus tip to the valley between villi. CD was measured from the muscular layer to the villus crypt baseline. In addition, the three thickest muscular layers were measured from the submucosal layer to the serosal layer of the intestinal walls. Mean VH (Villus Height), CD (Crypt Depth), VCR (VH : CD ratio) and muscular layer thickness were calculated and used for statistical analysis.

At the end of Experiment 2, blood samples were taken per replicate from the brachial vein and placed in heparinized tubes. Samples were put on ice immediately, and processed within 30 minutes of collection. Plasma was obtained by centrifuging the blood samples at $3000 \times g$ for 15 minutes at $4 \stackrel{\circ}{\circ}$. Plasma aliquots were kept frozen at $-20 \stackrel{\circ}{ } \mathrm{C}$ until analysed. Concentrations of free plasma AAs were measured with a model 3A30 Carlo Erba Amino Analyzer (Carlo Erba-Fisons, Rodano, Milan, Italy), as described (Marchesini et al., 1987).

To determine the AFD of AAs, excreta from each cage were collected for 6 - to 12-hour periods, depending on the amount of excretion, on day 4 (80 - 92 hours after hatch), day 7 (154 - 166 hours after hatch) and day 14 post hatch. Samples were homogenized using a PT 10/35 polytron mixer (Brinkmann Instruments, Westbury, NY), duplicated, and placed in a $-20{ }^{\circ} \mathrm{C}$ freezer. After less than a month, the samples were lyophilized and then milled, using a $0.5-\mathrm{mm}$ sieve. Nitrogen content of the samples was then determined using the procedure (Kjeldahl) described by AOAC (1995). Amino acid concentrations in the feed and excreta were determined using ion exchange chromatography following hydrolysis in $6 \mathrm{~N} \mathrm{HCl}$ for 24 hours at $110 \stackrel{\circ}{\circ}$ (Spackman et al., 1958). Analyses of methionine and cystine were conducted after performic acid oxidation (Moore, 1963; Chung et al., 1989). Tryptophan analysis was accomplished after 16 hours' alkaline (4 N LiOH) hydrolysis according to the procedure of Werner (1986).

On days 4,7 and 14 , four birds from each cage from each feeding group were stunned electrically and euthanized by exsanguination. Intestinal tracts were removed immediately, and the contents of the distal half of the ileum were collected by gently flushing with cold PBS into plastic containers. The collected digesta of the birds within a cage were pooled at the sampling time and mixed with $4.5 \%$ formic acid. These samples were stored in a freezer maintained at $-20^{\circ} \mathrm{C}$ in airtight containers until analysed. The samples were then lyophilized and ground through a $0.5-\mathrm{mm}$ sieve, and then divided in two. The following procedure was used: Nitrogen content by Kjeldahl method described by AOAC (1995) and chromic oxide after ashing at $450{ }^{\circ} \mathrm{C}$ 
Table 2 Composition (\% as dry matter basis) of the experimental diets (Experiment 1)

\begin{tabular}{|c|c|c|c|}
\hline \multirow{2}{*}{ Ingredient } & \multicolumn{3}{|c|}{ Experimental diets } \\
\hline & $0 \%$ Glutamine & $1 \%$ Glutamine & $2 \%$ Glutamine \\
\hline Maize & 457 & 457 & 457 \\
\hline Soybean meal & 384 & 384 & 384 \\
\hline Maltodextrin & 30 & 30 & 30 \\
\hline Calcium carbonate & 10 & 10 & 10 \\
\hline Soybean oil & 38 & 38 & 38 \\
\hline Choline chloride & 1.7 & 1.7 & 1.7 \\
\hline Vitamin premix $^{1}$ & 2 & 2 & 2 \\
\hline Mineral premix ${ }^{2}$ & 2 & 2 & 2 \\
\hline Dicalcium phosphate & 24.5 & 24.5 & 24.5 \\
\hline Sodium chloride & 1.7 & 1.7 & 1.7 \\
\hline Sodium bicarbonate $\left(\mathrm{NaHCO}_{3}\right)$ & 2.4 & 2.4 & 2.4 \\
\hline Chromium oxide premix ${ }^{3}$ & 20 & 20 & 20 \\
\hline Ethoxyquin & 0.2 & 0.2 & 0.2 \\
\hline DL-Methionine & 3.3 & 3.3 & 3.3 \\
\hline L-Lysine $\mathrm{HCl}$ & 2 & 2 & 2 \\
\hline L-Threonine & 1.2 & 1.2 & 1.2 \\
\hline L-Glutamine & 0 & 10 & 20 \\
\hline Cellulose & 20 & 10 & 0 \\
\hline Total & 1000 & 1000 & 1000 \\
\hline
\end{tabular}

\footnotetext{
1 Provided per kilogram of diet: thiamin, $2.3 \mathrm{mg}$; niacin, $29.5 \mathrm{mg}$; riboflavin, $6.2 \mathrm{mg}$; D-Ca-pantothenate, 16.4 $\mathrm{mg}$; vitamin $\mathrm{B}_{12}, 0.016 \mathrm{mg}$; pyridoxine $\cdot \mathrm{HCL}, 3.7 \mathrm{mg}$; D-biotin, $0.25 \mathrm{mg}$; folic acid, $0.86 \mathrm{mg}$; menadione dimethylpyrimidinol bisulfate, $2.65 \mathrm{mg}$; vitamin A (retinyl acetate), $12500 \mathrm{IU}$; vitamin D (cholecalciferol), $5000 \mathrm{IU}$; vitamin E ( $\alpha$-tocopheryl acetate), 70 IU.

${ }^{2}$ Provided per kilogram of diet: $\mathrm{MgSO}_{4} \cdot 5 \mathrm{H}_{2} \mathrm{O}, 3.1 \mathrm{~g} ; \mathrm{ZnCO}_{3}, 0.10 \mathrm{~g} ; \mathrm{ZnSO}_{4}, 0.4 \mathrm{~g}, \mathrm{CaCO}_{3}, 0.32 \mathrm{~g} ; \mathrm{MnSO}_{4} \cdot \mathrm{H}_{2} \mathrm{O}$, $0.65 \mathrm{~g} ; \mathrm{MnO}, 0.22 \mathrm{~g} ; \mathrm{FeSO}_{4} \cdot 7 \mathrm{H}_{2} \mathrm{O}, 0.42 \mathrm{~g} ; \mathrm{KI}, 43 \mathrm{mg} ; \mathrm{CuSO}_{4} \cdot 5 \mathrm{H}_{2} \mathrm{O}, 30 \mathrm{mg} ; \mathrm{Na}_{2} \mathrm{MoO}_{4} \cdot 2 \mathrm{H}_{2} \mathrm{O}, 10 \mathrm{mg} ; \mathrm{H}_{3} \mathrm{BO}_{3}, 8.6$ $\mathrm{mg} ; \mathrm{CoSO}_{4} \cdot 7 \mathrm{H}_{2} \mathrm{O}, 1.18 \mathrm{mg} ; \mathrm{Na}_{2} \mathrm{SeO}_{3}, 0.35 \mathrm{mg}$.

${ }^{3}$ Supplied $5 \mathrm{~g}$ chromic oxide per $\mathrm{kg}$ of diet. The premix was added at a ratio $1: 3$ of chromic oxide : corn starch.
}

(Fenton \& Fenton, 1979). Samples were analysed for AA concentration as described for faecal samples. Chrome was measured in samples of feed, excreta and ileal content in duplicate.

The AID coefficients of AAs that were evaluated in the experiments were calculated using the method of Ten Doeschate et al. (1993) from the formulae:

$$
\begin{aligned}
& \mathrm{DC}_{\text {diet }}=1-\left[\left(\mathrm{M}_{\text {diet }} / \mathrm{M}_{\mathrm{i}}\right) \times\left(\mathrm{Ci} / \mathrm{C}_{\text {diet }}\right)\right] \\
& \mathrm{DC}_{\mathrm{ti}}=\left(\mathrm{DC}_{\text {diet }} \times \mathrm{C}_{\text {diet }}-\mathrm{DC} \mathrm{C}_{\text {ref }} \times \mathrm{C}_{\text {ref }} \times 0.50\right) /\left(\mathrm{C}_{\text {diet }}-\mathrm{C}_{\text {ref }} \times 0.50\right),
\end{aligned}
$$

where $\mathrm{DC}_{\text {diet }}$ and $\mathrm{DC}_{\mathrm{ti}}$ are digestibility coefficients of an $\mathrm{AA}$ in the diet and test ingredient;

$M_{\text {diet }}$ and $M_{i}$ are chromic oxide content of the feed and the ileal digesta;

$\mathrm{C}_{i}, \mathrm{C}_{\text {diet }}$, and $\mathrm{C}_{\text {ref }}$ are the AA content of ileal digesta, the feed, and the reference diet; and

$\mathrm{DC}_{\text {ref }}$ is the digestibility coefficient for the reference diet, calculated using the same equation as for DC diet. coefficients.

The experiments were analysed statistically using the general lineal model ANOVA (version 9.2, SAS Institute Inc., Cary, NC) as a completely randomized design (SAS, 2001). Cage was considered an experimental unit. Means were compared using Duncan's multiple range test, and in all cases significance level was set at $P<0.05$. 
Table 3 Nutrient composition (dry matter basis) of the diets (Experiment 2)

\begin{tabular}{|c|c|c|c|c|}
\hline Ingredient (g/kg) & Casein & Glutamic acid & Glutamine & Glutamine + glutamic acid \\
\hline Dextrose & 220 & 220 & 220 & 220 \\
\hline Purified corn starch & 330 & 360 & 360 & 360 \\
\hline Maltodextrin & 45 & 45 & 45 & 45 \\
\hline Casein & 250 & 0 & 0 & 0 \\
\hline L-Glutamic acid & 0.00 & 48.80 & 0 & 24.40 \\
\hline L-Glutamine & 0.00 & 0.00 & 48.80 & 24.40 \\
\hline Cellulose & 73.89 & 81.31 & 81.31 & 81.31 \\
\hline Soybean oil & 5.10 & 5.10 & 5.10 & 5.10 \\
\hline Choline chloride & 3.30 & 3.30 & 3.30 & 3.30 \\
\hline Purified vitamin premix ${ }^{1}$ & 1.90 & 1.90 & 1.90 & 1.90 \\
\hline Mineral premix ${ }^{2}$ & 2.20 & 2.20 & 2.20 & 2.20 \\
\hline Calcium carbonate & 16.24 & 12.75 & 12.75 & 12.75 \\
\hline Dicalcium phosphate & 16.23 & 26.32 & 26.32 & 26.32 \\
\hline L-Arginine & 6.48 & 14.07 & 14.07 & 14.07 \\
\hline L-Lysine & 0.00 & 22.46 & 22.46 & 22.46 \\
\hline DL-Methionine & 3.44 & 11.02 & 11.02 & 11.02 \\
\hline L-Threonine & 0.10 & 9.75 & 9.75 & 9.75 \\
\hline L-Isoleucine & 0.00 & 11.66 & 11.66 & 11.66 \\
\hline L-Valine & 0.00 & 14.67 & 14.67 & 14.67 \\
\hline L-Leucine & 0.00 & 8.68 & 8.68 & 8.68 \\
\hline L-Tryptophan & 0.00 & 2.71 & 2.71 & 2.71 \\
\hline L-Histidine & 0.00 & 3.62 & 3.62 & 3.62 \\
\hline L-Phenylalanine & 0.00 & 11.36 & 11.36 & 11.36 \\
\hline Glycine & 0.68 & 5.03 & 5.03 & 5.03 \\
\hline L-Alanine & 0.00 & 6.50 & 6.50 & 6.50 \\
\hline L-Proline & 0.00 & 24.92 & 24.92 & 24.92 \\
\hline L-Aspartate & 0.00 & 15.40 & 15.40 & 15.40 \\
\hline Potassium chloride & 1.36 & 0.06 & 0.06 & 0.06 \\
\hline Sodium bicarbonate & 3.20 & 8.79 & 8.79 & 8.79 \\
\hline Potassium bicarbonate & 0.68 & 2.42 & 2.42 & 2.42 \\
\hline Chromic oxide premix ${ }^{4}$ & 20.00 & 20.00 & 20.00 & 20.00 \\
\hline Ethoxyquin & 0.20 & 0.20 & 0.20 & 0.20 \\
\hline Total & 1000 & 1000 & 1000 & 1000 \\
\hline
\end{tabular}

${ }^{1}$ Provided per kilogram of diet: thiamin (thiamin mononitrate), $5.5 \mathrm{mg}$; niacin, $70 \mathrm{mg}$; riboflavin, $11 \mathrm{mg}$;

D-Ca-pantothenate, $30 \mathrm{mg}$; vitamin $\mathrm{B}_{12}, 0.022 \mathrm{mg}$; pyridoxine. $\mathrm{HCL}, 6.5 \mathrm{mg}$; D-biotin, $0.43 \mathrm{mg}$; folic acid, $2.5 \mathrm{mg}$;

menadione dimethylpyrimidinol bisulfate, $4 \mathrm{mg}$; vitamin A (retinyl acetate), $12500 \mathrm{IU}$; vitamin D (cholecalciferol), $5000 \mathrm{IU}$; vitamin E (DL- $\alpha$-Tocopheryl acetate), $70 \mathrm{IU}$; ascorbic acid, $280 \mathrm{mg}$.

${ }^{2}$ Provided per kilogram of diet: $\mathrm{MgSO}_{4} \cdot 5 \mathrm{H}_{2} \mathrm{O}, 3.1 \mathrm{~g} ; \mathrm{ZnCO}_{3}, 0.10 \mathrm{~g} ; \mathrm{ZnSO}_{4}, 0.4 \mathrm{~g}, \mathrm{CaCO}_{3}, 0.32 \mathrm{~g} ; \mathrm{MnSO}_{4} \cdot \mathrm{H}_{2} \mathrm{O}, 0.65 \mathrm{~g}$; $\mathrm{MnO}, 0.22 \mathrm{~g} ; \mathrm{FeSO}_{4} \cdot 7 \mathrm{H}_{2} \mathrm{O}, 0.42 \mathrm{~g} ; \mathrm{Kl}, 43 \mathrm{mg} ; \mathrm{CuSO}_{4} \cdot 5 \mathrm{H}_{2} \mathrm{O}, 30 \mathrm{mg} ; \mathrm{Na}_{2} \mathrm{MoO}_{4} \cdot 2 \mathrm{H}_{2} \mathrm{O}, 10 \mathrm{mg} ; \mathrm{H}_{3} \mathrm{BO}_{3}, 8.6 \mathrm{mg}$;

$\mathrm{CoSO}_{4} \cdot 7 \mathrm{H}_{2} \mathrm{O}, 1.18 \mathrm{mg} ; \mathrm{Na}_{2} \mathrm{SeO}_{3}, 0.35 \mathrm{mg}$. The carrier was calcium carbonate, and the premix contained less than $0.7 \%$ mineral oil.

${ }_{3}^{3}$ Crystalline amino acids were assumed to be $100 \%$ digestible.

${ }^{4} 5 \mathrm{~g}$ chromic oxide per $\mathrm{kg}$ of diet. The premix was added at a ratio $1: 3$ of chromic oxide : corn starch. 
Table 4 Nutritional composition of diets (Experiment 2)

\begin{tabular}{lcccc}
\hline & \multicolumn{4}{c}{ Dietary treatments } \\
\cline { 2 - 4 } & Casein & Glutamic acid & Glutamine & $\begin{array}{c}\text { Glutamine }+ \\
\text { glutamic acid }\end{array}$ \\
\hline Analysed composition & & & & \\
$\quad$ Crude protein $(\mathrm{g} / \mathrm{kg})$ & 252.4 & 234.7 & 252 & 248.4 \\
Calcium $(\mathrm{g} / \mathrm{kg})$ & 11.1 & 11.1 & 11.0 & 11.0 \\
Lysine $(\mathrm{g} / \mathrm{kg})$ & 19.6 & 19.5 & 19.5 & 19.5 \\
Methionine $(\mathrm{g} / \mathrm{kg})$ & 10.9 & 10.9 & 11.6 & 11.6 \\
Methionine $+\mathrm{cystine}(\mathrm{g} / \mathrm{kg})$ & 11.9 & 11.9 & 11.9 & 11.9 \\
Threonine $(\mathrm{g} / \mathrm{kg})$ & 10.5 & 10.5 & 10.9 & 10.7 \\
Tryptophan $(\mathrm{g} / \mathrm{kg})$ & 3.1 & 3.2 & 3.0 & 3.0 \\
Arginine $(\mathrm{g} / \mathrm{kg})$ & 16.7 & 16.7 & 16.6 & 16.6 \\
Valine $(\mathrm{g} / \mathrm{kg})$ & 16.2 & 16.5 & 16.4 & 16.3 \\
Isoleucine $(\mathrm{g} / \mathrm{kg})$ & 12.8 & 12.7 & 12.7 & 12.8 \\
Calculated composition & & & & \\
$\quad$ Apparent metabolizable energy $(\mathrm{MJ} / \mathrm{kg})$ & & & 12.67 & \\
\hline
\end{tabular}

\section{Results}

Experiment 1: During days 0 to 14 after hatch, chickens that had ad libitum access to the $1 \%$ Gln supplemented diet had the highest average daily weight gain and average daily feed intake $(P<0.05)($ Table 5). The FCR was significantly $(P<0.05)$ better at $0-4,4-7$ and $7-14$ days old for chicks fed the $1 \%$ Glnsupplemented diet than for chicks fed the control and $2 \%$ Gln-supplemented diets. By seven days old, there were higher significant differences $(P<0.05)$ among chicks fed the experimental diets. The worst performances, including $A D G$ and $A D I$, were recorded for the $2 \%$ Gln-supplemented diet.

The AID and AFD coefficients of AAs were determined for the three dietary treatments in Experiment 1 (see Tables 6, 7 and 8). Supplementing diets with Gln increased almost all digestibility coefficients including AFD and AID for Arg, Lys, lle and Val in chickens at day 4 after hatch $(P<0.05)$. On the other hand, by increasing dietary Gln concentration, a significant drop in AID and AFD values was observed for Glu and Asp. These effects lasted and intensified until on day 7 post hatch an increase in the AID coefficient of Leu was seen for the $1 \%$ Gln-supplemented diet. On day 14 post hatch (Table 8), the impact of dietary treatments lessened and the differences were still significant only for Lys, Arg and Glu.

The intestinal morphometric parameters of three segments of small intestine of male broiler chicks in various treatments of Experiment 1 on days 4, 7 and 14 post hatch are presented in Table 9. On days 4 and 7 post hatch, there was a significant difference in the jejunum and ileum in VH and CD among treatments. Compared with the unsupplemented diet, birds fed the 1\% and $2 \%$ Gln-supplemented diets had higher $\mathrm{VH}$ and shallower CD of jejunum and ileum. At day 7 post hatch, the increase in height of VH was observed for both Gln-supplemented diets. The muscular layer thickness, excluded from ileum records on day 4 after hatch, which was higher for Gln supplemented diets, was not affected by dietary treatments. Compared with unsupplemented groups, on day 7 post hatch, birds in groups that Gln had higher VCR in all three segments of the intestine. This impact was observed for the jejunum on days 4 and 14 after hatch only.

Experiment 2: During the 0-4, 4- 7 and 7-14 day periods, performance was influenced significantly by dietary treatments (Table 10). In comparison with synthetic AA-based diets, which were fortified with Gln, Glu and a $1: 1$ blend of these two non-essential AAs, broiler chicken groups fed a diet based on casein as the source of intact protein presented higher ADG and better FCR at day 4 post hatch. This effect lasted partially in day 7 and 14 records. Casein-fed birds showed higher ADG and ADI at days 7 and 14 post hatch. For synthetic AA-based diets, lower FCR values were observed at all ages. In Experiment 2, none of the AID coefficient of AAs was influenced by the dietary source of AAs, except Glu and Asp $(P<0.05)$, which decreased clearly in broiler chicks fed Glu, Gln or a blend of the two (Table 11). This effect was not observed for Asp at day 7 of sampling. 
Table 5 Effect of dietary glutamine concentration on growth performance measured in 4-, 7- and 14-day-old male broiler chickens (Experiment 1)

\begin{tabular}{lcccc}
\hline \multirow{2}{*}{ Variable } & \multicolumn{3}{c}{ Supplemented glutamine level } & \multirow{2}{*}{ SEM } \\
\cline { 2 - 3 } & $\mathbf{0} \%$ & $\mathbf{1} \%$ & \\
\hline $\mathbf{0}$ - $\mathbf{4} \mathbf{~ d}$ & & & \\
ADG (g/d) & $15.97^{\mathrm{c}}$ & $17.13^{\mathrm{a}}$ & $16.89^{\mathrm{b}}$ & 0.32 \\
ADI (g/d) & $16.60^{\mathrm{b}}$ & $17.00^{\mathrm{a}}$ & $16.77^{\mathrm{b}}$ & 0.36 \\
FCR & $1.02^{\mathrm{a}}$ & $0.98^{\mathrm{b}}$ & $1.01^{\mathrm{a}}$ & 0.01 \\
$\mathbf{4}$ - $\mathbf{~ d ~}$ & & & \\
ADG (g/d) & $25.23^{\mathrm{b}}$ & $28.68^{\mathrm{a}}$ & $25.88^{\mathrm{b}}$ & 0.39 \\
ADI (g/d) & $33.30^{\mathrm{b}}$ & $36.30^{\mathrm{a}}$ & $33.90^{\mathrm{b}}$ & 0.40 \\
FCR & $1.30^{\mathrm{a}}$ & $1.26^{\mathrm{b}}$ & $1.31^{\mathrm{a}}$ & 0.01 \\
$\mathbf{7}$ - 14 d & & & & \\
ADG (g/d) & $36.94^{\mathrm{b}}$ & $38.74^{\mathrm{a}}$ & $34.32^{\mathrm{c}}$ & 0.57 \\
ADI (g/d) & 54.30 & 55.36 & 54.18 & 0.63 \\
FCR & $1.48^{\mathrm{b}}$ & $1.41^{\mathrm{c}}$ & $1.56^{\mathrm{a}}$ & 0.02 \\
\hline
\end{tabular}

a,b Different superscripts within a row indicate significant differences among treatments $(P<0.05)$.

ADG: average daily gain; ADI: average daily feed intake;

FCR: feed conversion ratio [(bodyweight-initial body weight) / cumulative feed intake].

Table 6 Effect of dietary glutamine concentration on apparent faecal digestibility (AFD) and apparent ileal digestibility (AID) coefficients (\%, mean) of amino acids in a complete diet measured in 4-day-old male broiler chickens (Experiment 1)

\begin{tabular}{|c|c|c|c|c|c|c|c|c|}
\hline \multirow{3}{*}{ Amino acids } & \multicolumn{6}{|c|}{ Supplemented glutamine level } & \multirow{3}{*}{$\begin{array}{l}\text { Pooled SEM } \\
\text { for AFD }\end{array}$} & \multirow{3}{*}{$\begin{array}{l}\text { Pooled SEM } \\
\text { for AID }\end{array}$} \\
\hline & \multicolumn{2}{|c|}{$0 \%$} & \multicolumn{2}{|c|}{$1 \%$} & \multicolumn{2}{|c|}{$2 \%$} & & \\
\hline & AFD & AID & AFD & AID & AFD & AID & & \\
\hline Lysine & 78 & $79^{c}$ & 79 & $81^{\mathrm{b}}$ & 80 & $84^{\mathrm{a}}$ & 0.80 & 0.63 \\
\hline Methionine & 84 & 84 & 84 & 84 & 84 & 84 & 0.97 & 0.93 \\
\hline Cysteine & 65 & 68 & 65 & 68 & 65 & 68 & 0.85 & 0.64 \\
\hline Isoleucine & $79^{\mathrm{b}}$ & $82^{\mathrm{b}}$ & $82^{\mathrm{a}}$ & $84^{\mathrm{a}}$ & $82^{\mathrm{a}}$ & $84^{\mathrm{a}}$ & 0.72 & 0.78 \\
\hline Valine & 78 & $81^{b}$ & 79 & $83^{\mathrm{a}}$ & 79 & $83^{\mathrm{a}}$ & 0.90 & 0.44 \\
\hline Leucine & 80 & 81 & 80 & 82 & 81 & 82 & 1.07 & 0.97 \\
\hline Threonine & 77 & 77 & 79 & 80 & 79 & 80 & 1.87 & 1.29 \\
\hline Tryptophan & 78 & 79 & 78 & 79 & 78 & 79 & 0.58 & 0.55 \\
\hline Histidine & 81 & 81 & 81 & 80 & 82 & 82 & 0.86 & 0.83 \\
\hline Phenylalanine & 75 & 77 & 75 & 77 & 74 & 77 & 1.04 & 0.66 \\
\hline Arginine & $73^{c}$ & $75^{\mathrm{c}}$ & $75^{\mathrm{b}}$ & $79^{b}$ & $78^{\mathrm{a}}$ & $82^{\mathrm{a}}$ & 0.61 & 0.46 \\
\hline Proline & 75 & 82 & 75 & 81 & 75 & 81 & 1.07 & 1.12 \\
\hline Glutamate & $82^{\mathrm{a}}$ & $77^{\mathrm{a}}$ & $82^{\mathrm{a}}$ & $77^{\mathrm{a}}$ & $79^{b}$ & $73^{\mathrm{b}}$ & 1.45 & 1.11 \\
\hline Aspartate & 78 & $79^{\mathrm{a}}$ & 79 & $79^{\mathrm{a}}$ & 78 & $74^{\mathrm{b}}$ & 1.77 & 1.17 \\
\hline Alanine & 80 & 80 & 80 & 80 & 79 & 79 & 1.39 & 1.47 \\
\hline Serine & 77 & 78 & 77 & 77 & 78 & 77 & 1.19 & 0.96 \\
\hline
\end{tabular}

a,b Different superscripts within a row indicate significant differences among treatments $(P<0.05)$.

AFD and AID records were compared separately. 
Table 7 Effect of dietary glutamine concentration on apparent faecal digestibility (AFD) and apparent ileal digestibility (AID) coefficients (\%, mean) of amino acids in a complete diet, measured in 7-day-old broiler chickens (Experiment 1)

\begin{tabular}{|c|c|c|c|c|c|c|c|c|}
\hline \multirow{3}{*}{ Amino acids } & \multicolumn{6}{|c|}{ Supplemented glutamine level } & \multirow{3}{*}{$\begin{array}{l}\text { Pooled SEM } \\
\text { for AFD }\end{array}$} & \multirow{3}{*}{$\begin{array}{l}\text { Pooled SEM } \\
\text { for AID }\end{array}$} \\
\hline & \multicolumn{2}{|c|}{$0 \%$} & \multicolumn{2}{|c|}{$1 \%$} & \multicolumn{2}{|c|}{$2 \%$} & & \\
\hline & AFD & AID & AFD & AID & AFD & AID & & \\
\hline Lysine & $85^{\mathrm{b}}$ & $85^{\mathrm{c}}$ & $87^{\mathrm{a}}$ & $88^{\mathrm{b}}$ & $88^{a}$ & $91^{\mathrm{a}}$ & 0.63 & 0.52 \\
\hline Methionine & 87 & 85 & 87 & 85 & 87 & 85 & 0.43 & 0.42 \\
\hline Cysteine & 73 & 76 & 75 & 76 & 75 & 76 & 0.47 & 0.40 \\
\hline Isoleucine & $85^{\mathrm{b}}$ & $85^{\mathrm{b}}$ & $87^{\mathrm{a}}$ & $88^{\mathrm{a}}$ & $87^{\mathrm{a}}$ & $88^{\mathrm{a}}$ & 0.62 & 0.68 \\
\hline Valine & $84^{\mathrm{b}}$ & $87^{\mathrm{b}}$ & $86^{\mathrm{b}}$ & $89^{b}$ & $85^{\mathrm{ab}}$ & $88^{\mathrm{ab}}$ & 0.29 & 0.28 \\
\hline Leucine & 86 & $88^{b}$ & 87 & $90^{\mathrm{a}}$ & 86 & $88^{\mathrm{b}}$ & 0.48 & 0.35 \\
\hline Threonine & 83 & 85 & 83 & 85 & 83 & 85 & 0.90 & 0.61 \\
\hline Tryptophan & 85 & 86 & 85 & 86 & 84 & 86 & 0.28 & 0.30 \\
\hline Histidine & 83 & 86 & 85 & 86 & 83 & 86 & 0.46 & 0.33 \\
\hline Phenylalanine & 81 & 85 & 80 & 85 & 80 & 85 & 0.68 & 0.69 \\
\hline Arginine & $86^{c}$ & $87^{c}$ & $89^{b}$ & $90^{\mathrm{b}}$ & $92^{\mathrm{a}}$ & $93^{\mathrm{a}}$ & 0.31 & 0.25 \\
\hline Proline & 88 & 89 & 88 & 89 & 87 & 89 & 0.33 & 0.24 \\
\hline Glutamate & $90^{\mathrm{a}}$ & $92^{\mathrm{a}}$ & $88^{b}$ & $89^{b}$ & $86^{c}$ & $84^{c}$ & 0.57 & 0.34 \\
\hline Aspartate & $86^{\mathrm{a}}$ & $88^{\mathrm{a}}$ & $83^{b}$ & $84^{b}$ & $83^{c}$ & $81^{\mathrm{c}}$ & 0.87 & 0.41 \\
\hline Alanine & 88 & 90 & 88 & 90 & 88 & 90 & 0.30 & 0.34 \\
\hline Serine & 86 & 87 & 85 & 87 & 85 & 86 & 0.66 & 0.50 \\
\hline
\end{tabular}

\footnotetext{
a,b Different superscripts within a row indicate significant differences among treatments $(P<0.05)$. AFD and AID records were compared separately.
}

\section{Discussion}

The effects of dietary CP content on the AID values of AA and protein have been reported in broilers (Donkoh \& Moughan, 1994), rats (Sarwar \& Peace, 1986; Donkon \& Moughan, 1994) and growing pigs (Furuya \& Kaji, 1989; Keith \& Bell, 1991; Fan et al., 1994), indicating that an increase of dietary protein might lead to a greater AID of AAs. Eggum (1973) illustrated that AFD of CP in soybean meal increased curvilinearly with increasing CP concentration in a rat diet. Comparably, an increase in AID values was reported as the dietary CP content increased from $4 \%$ to $24 \%$ in pigs, in which AID values gradually reached a plateaux and became independent of CP (Fan et al., 1994). Fan et al., (1994) reported quadratic plateau relationships between the dietary AA contents and their AID. AID alteration of Glu in response to its dietary content, unlike other AAs, tended to follow a pattern in which, after reaching the plateau, AID of Glu tended to decrease as its dietary level was increased (Fan et al., 1994). This decrease was observed in Experiment 1 , in which fortifying a diet with $2 \%$ Gln led to a decrease of AID and AFD coefficients of Glu. One of the most common theories to explain the decrease of AA absorption in high-protein diets is the limitation in uptake of free AAs and small peptides by enterocytes (Webb, 1990). In these circumstances, the concentration of free form AAs exceeds the maximum capacity of the intestinal transport system. Nevertheless, this theory did not make complete sense in the observations of the first experiment which, despite consistency of all dietary essential AAs, AID and AFD of Lys, Arg, Val, lle and Asp, were influenced by dietary Glu level. The presence of free form of AA in the lumen of the intestine, induces AA transport systems (Diamond \& Karasov, 1987) and the secretion of pancreatic proteases (Johnson, 2001). Thus, AAs in the lumen of the intestine from crystalline origin might boost the absorption capacity. The results of the second experiment - in which a perceptible amount of crystalline AA was replaced with casein as an intact protein-bound AA, but did not affect AID values apart from Glu and Asp - are conspicuous evidence that the quantity of free form of $A A$ in the intestine lumen does not play a major role in absorption and metabolism of AAs. Otto et al. (2003) reported that the presence of crystalline AA in reduced CP diets of growing pigs may raise AID values of all essential and non-essential AAs linearly. In contrast, Chung \& Baker (1992) reported 
higher digestibility values for protein-bound diets than crystalline AA-based diets in growing pigs and roosters. It remains puzzling that some interactions occur for intestinal absorption between intact proteinbound $A A$ and crystalline ones. The high inclusion of crystalline AA often results in a reduction of performance. This is attributed by some researchers to dwindling appetite (Han \& Baker, 1993; Carew et al., 1998; Si et al., 2004; Namroud et al., 2008; 2010). The drastic reduction in feed intake was observed in the second experiment in days $4-7$ and 7 - 14 post hatch owing to the exclusion of casein from the diet as the source of intact protein-bound AAs, but the AID and AFD values were not affected. The notable point in the present study was that the concentration of all essential AAs plus Gly, Pro, Ala, Asp + Asn and Glu + Gln remained constant, and the only variable was the source of Glu + Gln.

Table 8 Effect of dietary glutamine concentration on apparent faecal digestibility (AFD) and apparent ileal digestibility (AID) coefficients (\%, mean) of amino acid in a complete diet measured in 14-day-old broiler chickens (Experiment 1)

\begin{tabular}{|c|c|c|c|c|c|c|c|c|}
\hline \multirow{3}{*}{ Amino acids } & \multicolumn{6}{|c|}{ Supplemented glutamine level } & \multirow{3}{*}{$\begin{array}{l}\text { Pooled SEM } \\
\text { for AFD }\end{array}$} & \multirow{3}{*}{$\begin{array}{l}\text { Pooled SEM } \\
\text { for AID }\end{array}$} \\
\hline & \multicolumn{2}{|c|}{$0 \%$} & \multicolumn{2}{|c|}{$1 \%$} & \multicolumn{2}{|c|}{$2 \%$} & & \\
\hline & AFD & AID & AFD & AID & AFD & AID & & \\
\hline Lysine & $89^{b}$ & $90^{\mathrm{b}}$ & $90^{\mathrm{ab}}$ & $93^{\mathrm{a}}$ & $91^{\mathrm{a}}$ & $93^{a}$ & 0.54 & 0.39 \\
\hline Methionine & 89 & 88 & 89 & 89 & 88 & 88 & 0.89 & 0.66 \\
\hline Cysteine & 79 & 80 & 79 & 79 & 80 & 79 & 0.93 & 0.47 \\
\hline Isoleucine & 88 & 90 & 88 & 89 & 87 & 90 & 0.99 & 0.61 \\
\hline Valine & 89 & 89 & 88 & 90 & 89 & 90 & 1.05 & 0.63 \\
\hline Leucine & 87 & 90 & 87 & 90 & 88 & 89 & 0.58 & 0.44 \\
\hline Threonine & 88 & 88 & 88 & 89 & 88 & 88 & 1.37 & 0.77 \\
\hline Tryptophan & 90 & 92 & 91 & 91 & 89 & 90 & 0.40 & 0.32 \\
\hline Histidine & 89 & 89 & 88 & 89 & 88 & 89 & 0.46 & 0.39 \\
\hline Phenylalanine & 88 & 88 & 86 & 89 & 87 & 88 & 0.86 & 0.75 \\
\hline Arginine & 90 & $90^{b}$ & 90 & $93^{a}$ & 92 & $94^{a}$ & 1.75 & 0.39 \\
\hline Proline & 92 & 95 & 93 & 93 & 92 & 93 & 0.56 & 0.28 \\
\hline Glutamate & 94 & $93^{b}$ & 92 & $95^{\mathrm{a}}$ & 94 & $96^{a}$ & 0.84 & 0.88 \\
\hline Aspartate & 94 & 97 & 94 & 96 & 93 & 95 & 1.15 & 0.80 \\
\hline Alanine & 94 & 96 & 92 & 95 & 93 & 95 & 0.66 & 0.39 \\
\hline Serine & 95 & 95 & 95 & 94 & 94 & 93 & 0.92 & 0.52 \\
\hline
\end{tabular}

a,b Different superscripts within a row indicate significant differences among treatments $(P<0.05)$. AFD and AID records were compared separately.

With regard to gastrointestinal development, Maiorka et al., (2000) reported that $1 \%$ Gln supplementation led to positive effects on VH, CD and the VCR in the duodenum and on VH in the ileum at 7 days of age. According to the current findings, Gln supplementation (Experiment 1) led to overall improvement in intestinal morphology, including VH, CD and VCR, until 14 days old. In partial agreement with these findings, Nassiri Moghaddam \& Alizadeh-Ghamsari (2013) reported the beneficial influence of 1\% or $1.5 \%$ Gln supplementation of diet on increases in VH and villus surface area of the duodenum and jejunum of 21 and 42-day-old broilers. Benefits from Gln supplementation on small intestine morphology of chicks were observed by Khempaka et al. (2011). Pohlenz et al. (2012) demonstrated the efficient utilization of Gln by intestinal mucosal cells of channel catfish, which led to improvement of intestinal microstructure. However, this did not result in improved growth performance at the end of the trial. The positive influence of 
Gln and Arg supplementation on morphological measurements and probable nutrient absorption of the gastrointestinal tract was seen in hybrid striped bass (Cheng et al., 2012). The results of Experiment 1 indicate that, along with better performance, diets supplemented with Gln resulted in better development of the intestinal mucosa in neonate broiler chickens. Longer villi and higher VCR facilitate the absorption of nutrients due to increased absorption area, thereby potentially influencing the digestibility values of AA.

Table 9 Intestinal morphology of the small intestine of broiler chickens on days 4, 7 and 14 post hatch in various treatments (Experiment 1)

\begin{tabular}{|c|c|c|c|c|c|c|c|c|c|c|c|c|}
\hline \multirow{2}{*}{ Treatment } & \multicolumn{3}{|c|}{ Villus height $(\mu \mathrm{m})$} & \multicolumn{3}{|c|}{ Crypt depth $(\mu \mathrm{m})$} & \multicolumn{3}{|c|}{$\begin{array}{l}\text { Muscular layer } \\
\text { thickness }(\mu \mathrm{m})\end{array}$} & \multicolumn{3}{|c|}{$\mathrm{VH}: \mathrm{CD}$ ratio } \\
\hline & D & $\mathbf{J}$ & I & D & $\mathbf{J}$ & I & D & $\mathbf{J}$ & I & D & $\mathbf{J}$ & 1 \\
\hline \multicolumn{13}{|c|}{ Day 4 post hatch } \\
\hline $0 \%$ Gln & 453.5 & $411.5^{\mathrm{b}}$ & $212.8^{C}$ & 100.8 & $94.4^{\mathrm{a}}$ & $77.9^{\mathrm{a}}$ & 138 & 160 & $103^{\mathrm{b}}$ & 4.5 & $4.4^{\mathrm{b}}$ & 2.7 \\
\hline $1 \%$ Gln & 451.5 & $463.2^{\mathrm{a}}$ & $233.9^{b}$ & 100.5 & $85.0^{\mathrm{b}}$ & $76.5^{\mathrm{a}}$ & 142 & 160 & $133^{\mathrm{a}}$ & 4.5 & $5.4^{\mathrm{a}}$ & 3.1 \\
\hline $2 \%$ Gln & 460.1 & $470.2^{\mathrm{a}}$ & $247.5^{\mathrm{a}}$ & 102.1 & $84.3^{\mathrm{b}}$ & $70.3^{\mathrm{b}}$ & 143 & 164 & $134^{\mathrm{a}}$ & 4.5 & $5.6^{\mathrm{a}}$ & 3.5 \\
\hline SEM & 11.61 & 10.17 & 7.05 & 3.36 & 2.11 & 1.42 & 7.27 & 8.16 & 4.58 & 0.12 & 0.24 & 0.18 \\
\hline \multicolumn{13}{|c|}{ Day 7 post hatch } \\
\hline $0 \% \mathrm{Gln}$ & $605.9^{b}$ & $530.9^{b}$ & $251.4^{\mathrm{b}}$ & 155.4 & $127.7^{\mathrm{a}}$ & $80.2^{\mathrm{a}}$ & 175 & 178 & 129 & $3.9^{b}$ & $4.2^{b}$ & $3.1^{b}$ \\
\hline $1 \%$ Gln & $688.4^{\mathrm{a}}$ & $615.7^{\mathrm{a}}$ & $303.8^{a}$ & 153.0 & $105.6^{\mathrm{b}}$ & $75.1^{\mathrm{b}}$ & 172 & 173 & 134 & $4.5^{\mathrm{a}}$ & $5.8^{\mathrm{a}}$ & $4.0^{\mathrm{a}}$ \\
\hline $2 \%$ Gln & $695.1^{\mathrm{a}}$ & $608.1^{\mathrm{a}}$ & $310.2^{a}$ & 156.3 & $103.6^{\mathrm{b}}$ & $73.6^{\mathrm{b}}$ & 170 & 177 & 136 & $4.4^{\mathrm{a}}$ & $5.9^{\mathrm{a}}$ & $4.2^{\mathrm{a}}$ \\
\hline SEM & 14.93 & 12.26 & 11.07 & 4.01 & 2.85 & 1.48 & 8.02 & 12.49 & 9.41 & 0.15 & 0.20 & 0.21 \\
\hline \multicolumn{13}{|c|}{ Day 14 post hatch } \\
\hline $0 \%$ Gln & 1217.5 & $936.1^{b}$ & $689.6^{\mathrm{b}}$ & 192.7 & 190.5 & 96.7 & 168 & 178 & 131 & 6.3 & $4.9^{b}$ & 7.2 \\
\hline $1 \%$ Gln & 1231.7 & $1104.8^{\mathrm{a}}$ & $719.8^{\mathrm{a}}$ & 188.1 & 185.4 & 95.2 & 174 & 186 & 133 & 6.5 & $6.0^{\mathrm{a}}$ & 7.6 \\
\hline $2 \%$ Gln & 1227.1 & $955.7^{b}$ & $680.1^{b}$ & 192.2 & 189.1 & 93.7 & 170 & 183 & 135 & 6.4 & $5.0^{b}$ & 7.3 \\
\hline SEM & 24.56 & 17.44 & 11.15 & 5.59 & 3.67 & 4.60 & 11.51 & 13.30 & 12.70 & 0.22 & 0.28 & 0.38 \\
\hline
\end{tabular}

${ }^{a, b}$ Different superscripts in a column of each period indicate significant differences among treatments $(P<0.05)$. Gln: glutamine; D: duodenum; J: jejunum; I: ileum.

An indicative influence of dietary GIn on the AID and AFD values of cationic, branched-chain and anionic AA was found in the first study. Raising the dietary Gln level from $0 \%$ to $2 \%$ resulted in higher AFD and AID coefficients for cationic AAs, except histidine, but, conversely, led to a lower digestibility coefficient for anionic AAs involving Glu and Asp. The increase in AID and AFD with increasing dietary Gln was found for branched-chain AAs, including Ile, Leu and Val. The results of first study support the effect of dietary Gln on other AA digestibilities. To the authors' knowledge, the effect of GIn on ADI of other AAs has not been studied in poultry, but the reduced impact of high dosage dietary Glu on the AID value of Glu has been reported in pigs (Fan et al., 1994). The results of the second experiment showed that no differences between free and protein-bound forms of dietary Gln and/or Glu impact on AA digestibilities, except for Glu and Asp. The dietary free form of Glu and Gln led to a decrease of AID values of Asp and Glu, which were not seen in the protein-bound form (casein) dietary treatment. The effect of dietary protein quality and quantity on the expression of AA transporter genes in brush border membrane of intestine was reported (Chen et al., 2005; Gilbert et al., 2008). Amino acids, particularly Gln, can be used as source of energy. To complicate matters, enterocytes express transporter molecules with overlapping substrate specificity at a different velocity, which mediates the absorption of AAs (Karasov et al., 1987; Gilbert et al., 2008). The lack of data and complications of transporter responses to affecters, including nutritional parameters, make it difficult to predict transporter regulation in response to certain AAs or imbalances among AAs. Although the effect of Gln on molecular characteristics of the AA transporter was not studied in the present experiment, it may have undefined effects according to its clear influence on digestibility of certain limiting AAs, including Lys, Arg, Ile and $\mathrm{Val}$, and the development of morphometric parameters of the intestine. Greater knowledge of the ways in which dietary Gln may regulate the expression and activity of transporter genes (velocity and specificity) 
Table 10 Effect of glutamine (Gln) and glutamic acid source (Glu) on the growth performance measured in 4-, 7- and 14-day old male broiler chickens (Experiment 2)

\begin{tabular}{|c|c|c|c|c|c|}
\hline \multirow{2}{*}{ Variable } & \multicolumn{4}{|c|}{ Glutamine and glutamic acid source } & \multirow{2}{*}{ SEM } \\
\hline & Casein & GIn & Glu & Gln + Glu & \\
\hline \multicolumn{6}{|l|}{0 - 4 days } \\
\hline$A D G(g / d)$ & $14.84^{\mathrm{a}}$ & $13.13^{b}$ & $13.03^{b}$ & $13.38^{\mathrm{b}}$ & 0.41 \\
\hline ADI $(g / d)$ & 15.04 & 14.13 & 14.07 & 14.31 & 0.37 \\
\hline FCR & $1.01^{\mathrm{b}}$ & $1.07^{\mathrm{a}}$ & $1.08^{\mathrm{a}}$ & $1.07^{\mathrm{a}}$ & 0.02 \\
\hline \multicolumn{6}{|l|}{4 - 7days } \\
\hline$A D G(g / d)$ & $22.39^{\mathrm{a}}$ & $19.08^{\mathrm{b}}$ & $19.68^{\mathrm{b}}$ & $18.63^{\mathrm{b}}$ & 0.45 \\
\hline$A D I(g / d)$ & $25.47^{\mathrm{a}}$ & $19.61^{\mathrm{b}}$ & $19.93^{b}$ & $19.80^{b}$ & 0.57 \\
\hline FCR & $1.14^{\mathrm{a}}$ & $1.02^{\mathrm{C}}$ & $1.01^{\mathrm{c}}$ & $1.06^{\mathrm{b}}$ & 0.02 \\
\hline \multicolumn{6}{|l|}{$7-14 d$} \\
\hline$A D G(g / d)$ & $33.72^{\mathrm{a}}$ & $24.39^{b}$ & $25.04^{b}$ & $24.59^{b}$ & 0.52 \\
\hline ADI $(g / d)$ & $48.87^{\mathrm{a}}$ & $33.06^{\mathrm{b}}$ & $32.75^{b}$ & $33.53^{b}$ & 0.69 \\
\hline FCR & $1.45^{\mathrm{a}}$ & $1.35^{\mathrm{b}}$ & $1.31^{\mathrm{b}}$ & $1.36^{\mathrm{b}}$ & 0.04 \\
\hline
\end{tabular}

a,b Different superscripts within a row indicate significant differences among treatments $(P<0.05)$.

ADG: average daily gain; ADI: average daily feed intake.

FCR: feed conversion ratio $=[($ bodyweight-initial bodyweight $) /$ cumulative feed intake $]$.

Table 11 Effect of glutamine (Gln) and glutamic acid source (Glu) on apparent ileal digestibility coefficient $(\%$, mean) of amino acids in a completely purified diet (Experiment 2$)$

\begin{tabular}{|c|c|c|c|c|c|c|c|c|c|c|c|c|c|c|c|c|}
\hline & \multicolumn{16}{|c|}{ Amino acids } \\
\hline & Lys & Met & Cys & Ile & Leu & Val & Thr & Trp & His & Arg & Phe & Pro & Glu & Asp & Ala & Ser \\
\hline \multicolumn{17}{|c|}{ Day 4 post hatch } \\
\hline Casein & 90 & 93 & 88 & 94 & 94 & 93 & 90 & 91 & 95 & 90 & 92 & 95 & $94^{\mathrm{a}}$ & $95^{\mathrm{a}}$ & 90 & 90 \\
\hline Gln & 91 & 95 & 88 & 93 & 94 & 93 & 91 & 92 & 94 & 92 & 95 & 93 & $87^{b}$ & $91^{\mathrm{b}}$ & 91 & 90 \\
\hline Glu & 90 & 95 & 88 & 94 & 94 & 92 & 88 & 92 & 96 & 90 & 95 & 94 & $84^{\mathrm{c}}$ & $92^{\mathrm{b}}$ & 92 & 90 \\
\hline $\mathrm{Gln}+\mathrm{Glu}$ & 92 & 95 & 88 & 94 & 92 & 91 & 91 & 93 & 94 & 90 & 93 & 93 & $89^{b}$ & $90^{\mathrm{b}}$ & 90 & 90 \\
\hline SEM & 0.54 & 0.79 & 0.26 & 0.54 & 0.58 & 0.81 & 1.57 & 0.42 & 1.11 & 0.85 & 1.32 & 0.92 & 0.83 & 0.66 & 0.59 & 0.76 \\
\hline \multicolumn{17}{|c|}{ Day 7 post hatch } \\
\hline Casein & 95 & 95 & 89 & 97 & 96 & 95 & 95 & 96 & 95 & 95 & $93^{b}$ & 94 & $96^{\mathrm{a}}$ & 96 & 96 & 94 \\
\hline Gln & 97 & 93 & 89 & 95 & 95 & 95 & 95 & 95 & 96 & 94 & $96^{\mathrm{a}}$ & 95 & $92^{b}$ & 95 & 96 & 96 \\
\hline Glu & 96 & 95 & 90 & 95 & 96 & 96 & 95 & 95 & 96 & 94 & $96^{\mathrm{a}}$ & 96 & $93^{b}$ & 95 & 96 & 95 \\
\hline Gln+Glu & 96 & 95 & 90 & 95 & 96 & 95 & 94 & 94 & 95 & 94 & $96^{\mathrm{a}}$ & 94 & $92^{b}$ & 95 & 96 & 95 \\
\hline SEM & 0.97 & 0.66 & 0.57 & 0.94 & 0.80 & 0.73 & 1.41 & 1.03 & 0.64 & 0.86 & 0.71 & 1.05 & 0.93 & 0.88 & 0.54 & 0.99 \\
\hline \multicolumn{17}{|c|}{ Day 14 post hatch } \\
\hline Casein & 95 & 94 & 93 & 95 & 96 & 96 & 94 & 97 & 96 & 97 & 96 & 97 & $96^{\mathrm{a}}$ & $97^{\mathrm{a}}$ & 95 & 96 \\
\hline Gln & 95 & 94 & 92 & 96 & 97 & 95 & 94 & 98 & 97 & 97 & 96 & 98 & $91^{b}$ & $93^{b}$ & 95 & 96 \\
\hline Glu & 96 & 93 & 92 & 96 & 96 & 95 & 94 & 98 & 97 & 98 & 96 & 96 & $89^{b}$ & $93^{\mathrm{b}}$ & 96 & 96 \\
\hline $\mathrm{Gln}+\mathrm{Glu}$ & 95 & 93 & 91 & 96 & 96 & 95 & 93 & 98 & 96 & 97 & 96 & 97 & $91^{b}$ & $94^{\mathrm{b}}$ & 94 & 97 \\
\hline SEM & 0.52 & 0.57 & 0.78 & 0.64 & 0.83 & 0.70 & 1.05 & 0.41 & 0.59 & 0.82 & 0.63 & 1.26 & 1.15 & 1.04 & 0.80 & 0.67 \\
\hline
\end{tabular}

${ }^{\mathrm{a}, \mathrm{b}}$ Different superscripts within a column of each period indicate significant differences among means $(P<0.05)$.

Lys: Iysine, Met: methionine, Cys: cystine, Thr: threonine, Trp: tryptophan, Arg: arginine, Val: valine, Isu: isoleucine, Leu: leucine, His: histidine. 
would allow the discovery of ways to manipulate regulatory mechanisms to increase the capacity and efficiency of limiting AA absorption, and, thereby, optimization of dietary AA balance.

Feeding diets with a high level of synthetic AA resulted in increased blood ammonia level and decreased plasma uric acid concentration (Namroud et al., 2008). Noda (1975) confirmed that the blood ammonia level may act as a signal to regulate appetite in rats. Intraportal infusion of a small amount of ammonia salts led to depression of appetite in fasted dogs (Russek, 1971). The current observations in Experiment 2 - including lower daily feed intake and subsequent lower bodyweight gain in newly hatched broiler chickens fed free AA-included diets - was in agreement with the authors' previous study in 2008. According to blood ammonia records in Experiment 2 (not published), aminostatic hypothesis (Leung \& Rogers, 1969; Peng \& Harper, 1970) may play a role in the control of appetite.

\section{Conclusion}

In conclusion, 1\% L-Gln supplementation to post-hatch broilers, along with improvement in performance, modified the mucosal integrity of the small intestine, and led to increments in the digestibility values of certain AAs, including L-Lys, L-Arg, L-Ile and L-Val, which could be used to manipulate dietary AA as an economic strategy. Although excluding intact protein-bound AAs and supplementing Gln in crystalline form in diets affected performance and morphometric parameters negatively, they did not influence the digestibility values of other amino acids.

\section{Acknowledgements}

We gratefully acknowledge Degussa AG for conducting the amino acid analyses of our feedstuffs and providing crystalline amino acids.

\section{Authors' Contributions}

The research was conducted as part of NFN's PhD thesis in Poultry Nutrition. MS, MZ and OM supervised the whole study. KN and NFN did the statistical analyses. Finally, all authors commented on early and final versions of the manuscript.

\section{Conflict of Interest Declaration}

The authors have declared that there is no conflict of interests.

\section{References}

AOAC international, 2015. Official methods of analysis of AOAC International. AOAC International.

Becak, W. \& Paulete, J., 1976. Técnicas de citologia e histologia. Nobel. (in Spanish)

Biolo, G., Zorat, Z., Antonione, R. \& Ciocchi, B., 2005. Muscle glutamine depletion in the intensive care unit. Int. J. Biochem. Cell. B. 37, 2169-2179.

Carew, L.B., Evarts, K.G. \& Alster, F.A., 1998. Growth, feed intake, and plasma thyroid hormone levels in chicks fed dietary excesses of essential amino acids. Poult. Sci. 77, 295-298.

Chen, H., Pan, Y., Wong, E.A. \& Webb, K.E., 2005. Dietary protein level and stage of development affect expression of an intestinal peptide transporter (cPepT1) in chickens. J. Nutr. 135,193-198.

Cheng, Z., Gatlin III, D.M. \& Buentello, A., 2012. Dietary supplementation of arginine and/or glutamine influences growth performance, immune responses and intestinal morphology of hybrid striped bass. Aqua. 362, 39-43.

Chung, T.K. \& Baker, D.H., 1992. Apparent and true amino acid digestibility of a crystalline amino acid mixture and of casein: Comparison of values obtained with ileal-cannulated pigs and cecectomized cockerels. J. Anim. Sci. 70, 3781-3790.

Curthoys, N.P. \& Watford, M., 1995. Regulation of glutaminase activity and glutamine metabolism. Annu. Rev. Nutr. 15, 133-159.

Dai, S.F., Wang, L.K., Wen, A.Y., Wang, L.X. \& Jin, G.M., 2009. Dietary glutamine supplementation improves growth performance, meat quality and color stability of broilers under heat stress. Br. Poult. Sci. 50, 333-340.

Dai, S.F., Gao, F., Zhang, W.H., Song, S.X., Xu, X.L. \& Zhou, G.H., 2011. Effects of dietary glutamine and gammaaminobutyric acid on performance, carcass characteristics and serum parameters in broilers under circular heat stress. Anim. Feed. Sci. Technol. 168, 51-60.

Dai, M., Xia, X.B. \& Xiong, S.Q., 2012. BDNF regulates GLAST and glutamine synthetase in mouse retinal Müller cells. J. Cell. Physiol. 227 (2), 596-603.

Diamond, J.M. \& Karasov, W.H., 1987. Adaptive regulation of intestinal nutrient transporters. Proc. Nation. Acad. Sci. 84, $2242-2245$.

Donkoh, A. \& Moughan, P.J., 1994. The effect of dietary crude protein content on apparent and true ileal nitrogen and amino acid digestibilities. Br. J. Nutr. 72, 59-68.

Eggum, B.O., 1973. Study of certain factors influencing protein utilization in rats and pigs. http://agris.fao.org/aos/records/US201300503230.

Fan, M.Z., Sauer, W.C., Hardin, R.T. \& Lien, K.A., 1994. Determination of apparent ileal amino acid digestibility in pigs: Effect of dietary amino acid level. J. Anim. Sci. 72, 2851-2859. 
Fenton, T.W. \& Fenton, M., 1979. An improved procedure for the determination of chromic oxide in feed and feces. Can. J. Anim. Sci. 59, 631-634.

Furuya, S. \& Kaji, Y., 1989. Estimation of the true ileal digestibility of amino acids and nitrogen from their apparent values for growing pigs. Anim. Feed. Sci. Technol. 26, 271-285.

Gilbert, E.R., Li, H., Emmerson, D.A., Webb, K.E. \& Wong, E.A., 2008. Dietary protein quality and feed restriction influence abundance of nutrient transporter mRNA in the small intestine of broiler chicks. J. Nutr. 138, 262-271.

Gous, R.M., 2010. Nutritional limitations on growth and development in poultry. Livest. Sci. 130, 25-32.

Hada, F.H., Malheiros, R.D., Silva, J.D.T., Marques, R.H., Gravena, R.A., Silva, V.K. \& Moraes, V.M.B., 2013. Effect of protein, carbohydrate, lipid, and selenium levels on the performance, carcass yield, and blood changes in broilers. Rev. Bras. Cienc. Avic. 15, 385-394.

Han, Y. \& Baker, D.H., 1993. Effects of sex, heat stress, body weight, and genetic strain on the dietary lysine requirement of broiler chicks. Poult. Sci. 72, 701-708.

Karasov, H., William, H. David \& Diamond, J.M., 1987. Dependence of intestinal amino acid uptake on dietary protein or amino acid levels. Am. J. Physiol. 252, 614-625.

Keith, M.O. \& Bell, J.M., 1991. Composition and digestibility of canola press cake as a feedstuff for use in swine diets. Can. J. Anim. Sci. 71, 879-885.

Khan, J., liboshi, Y., Cui, L., Wasa, M., Sando, K., Takagi, Y. \& Okada, A., 1999. Alanyl-glutamine-supplemented parenteral nutrition increases luminal mucus gel and decreases permeability in the rat small intestine. JPENParenter Enter. 23, 24-31.

Khempaka, S., Chitsatchapong, C. \& Molee, W., 2011. Effect of chitin and protein constituents in shrimp head meal on growth performance, nutrient digestibility, intestinal microbial populations, volatile fatty acids, and ammonia production in broilers. J. Appl. Poult. Res. 1, 1-11.

Leung, P. \& Rogers, Q.R., 1969. Food intake: regulation by plasma amino acid pattern. Life. Sci.8, 1-9.

Maiorka, A., Silva, A.V.F., Santin, E., Borges, S.A., Boleli, I.C. \& Macari, M., 2000. Influence of glutamine supplementation on performance and intestinal villous and crypt development in broiler chickens. Arq. Bras. Med. Vet. Zoo. 52, 487-490.

Marchesini, G., Bianchi, G.P., Vilstrup, H., Checchia, G.A., Patrono, D. \& Zoli, M., 1987. Plasma clearances of branchedchain amino acids in control subjects and in patients with cirrhosis. J. Hepatol. 4, 108-117.

Murakami, A.E., Sakamoto, M.I., Natali, M.R.M., Souza, L.M.G. \& Franco, J.R.G., 2007. Supplementation of glutamine and vitamin $\mathrm{E}$ on the morphometry of the intestinal mucosa in broiler chickens. Poult. Sci. 86, 488-495.

Namroud, N.F., Shivazad, M. \& Zaghari, M., 2008. Effects of fortifying low crude protein diet with crystalline amino acids on performance, blood ammonia level, and excreta characteristics of broiler chicks. Poult. Sci. 87, 2250-2258.

Namroud, N.F., Shivazad, M. \& Zaghari, M., 2010. Impact of dietary crude protein and amino acids status on performance and some excreta characteristics of broiler chicks during 10 - 28 days of age. J. Anim. Phys. Anim. Nutr. 94, 280-286.

Nassiri Moghaddam, H. \& Alizadeh-Ghamsari, A.H., 2013. Improved performance and small intestinal development of broiler chickens by dietary L-glutamine supplementation. J. Appl. Anim. Res. 41, 1-7.

Noda, K., 1975. Possible effect of blood ammonia on food intake of rats fed amino acid imbalanced diets. J. Nutr. 105, 508-516.

Noy, Y. \& Skalan, D., 2002. Nutrient use in chicks during the first week post hatch. Poult. Sci. 81, 391-399.

Noy, Y. \& Uni, Z., 2010. Early nutritional strategies. World Poult. Sci. J. 66, 639-646.

NRC, 1994. Nutrient Requirements of Poultry. 9th rev. ed. Natl. Acad. Press. Washington, DC., USA.

Otto, E.R., Yokoyama, M., Ku, P.K., Ames, N.K. \& Trottier, N.L., 2003. Nitrogen balance and ileal amino acid digestibility in growing pigs fed diets reduced in protein concentration. J. Anim. Sci. 81, 1743-1753.

Panda, A.K., Prakash, B., Rama Rao, S.V., Raju, M.V.L.M. \& Shyam Sunder, G., 2013. Utilization of high quality protein maize in poultry. World Poult. Sci. J. 69, 877-888.

Peng, Y., \& Harper, A.E., 1970. Amino acid balance and food intake: effect of different dietary amino acid patterns on the plasma amino acid pattern of rats. J. Nutr. 100, 429-437.

Pohlenz, C., Buentello, A., Mwangi, W. \& Gatlin III, D.M., 2012. Arginine and glutamine supplementation to culture media improves the performance of various channel catfish immune cells. Fish. Shellfish. Immun. 32, 762-768.

Russek, M., 1981. Current status of the hepatostatic theory of food intake control. Appetite 2, 137-143.

Sarwar, G. \& Peace, R.W., 1986. Comparisons between true digestibility of total nitrogen and limiting amino acids in vegetable proteins fed to rats. J. Nutr. 116, 1172-1184.

SAS User's guide. 2001. Version 8 ed. SAS Inst. Inc., Cary, NC., USA.

Si, J., Fritts, C.A., Burnham, D.J. \& Waldroup, P.W., 2004. Extent to which crude protein may be reduced in cornsoybean meal broiler diets through amino acid supplementation. Int. J. Poult. Sci. 3, 46-50.

Souba, W.W., 1993. Glutamine and cancer. Ann. Surg. 218, 715-728.

Spackman, D.H., Stein, W.H. \& Moore, S., 1958. Automatic recording apparatus for use in chromatography of amino acids. Anal. Chem. 30, 1190-1206.

Swennen, Q., Everaert, N., Debonne, M., Verbaeys, I., Careghi, C., Tona, K., Janssens, G.P.J., Decuypere, E., Bruggeman, V. \& Buyse, J., 2010. Effects of macronutrient ratio of the pre-starter diet on broiler performance and intermediary metabolism. J. Anim. Physiol. An. N. 94, 375-384.

Ten Doeschate, R., Scheele, C.W., Schreurs, V.V.A.M. \& Van der Klis, J.D., 1993. Digestibility studies in broiler chickens: influence of genotype, age, sex and method of determination. Br. Poult. Sci. 34, 131-146.

Uni, Z., Noy, Y. \& Skalan, D., 1995. Post hatch changes in morphology and function of the small intestines in heavy-and light-strain chicks. Poult. Sci. 74, 1622-1629. 
Webb, K.E., 1990. Intestinal absorption of protein hydrolysis products: A review. J. Anim. Sci. 68, 3011-3022.

Yi, G.F., Carroll, J.A., Allee, G.L., Gaines, A.M., Kendall, D.C., Usry, J.L. \& Izuru, S., 2005. Effect of glutamine and spraydried plasma on growth performance, small intestinal morphology, and immune responses of Escherichia coli K88+-challenged weaned pigs. J. Anim. Sci. 83, 634-643. 